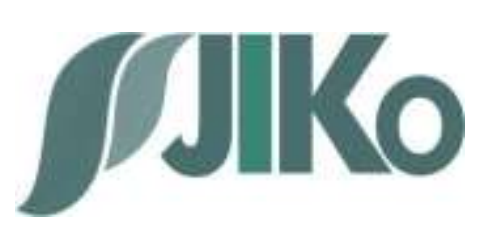

\title{
The Economic Impact of the Covid-19 Outbreak : Evidence from Indonesia
} Herninda Pitaloka ${ }^{1}$,Ahmad Ulil Albab Al Umar ${ }^{2}$, EkaResmi Hartati $^{3}$, Dessy Fitria ${ }^{4}$

Fakulty Economic and Business Islam, IAIN Salatiga, hernindapitaloka2@gmail.com, Indonesia ${ }^{1}$

Fakulty Economic and Business Islam, IAIN Salatiga, ahmadulil.asfebi@gmail.com, Indonesia ${ }^{2}$

Fakulty Economic and Business Islam, IAIN Salatiga, ekaresmihartati3020@gmail.com, Indonesia ${ }^{3}$

Fakulty Economic and Business Islam, IAIN Salatiga, dessyfitria.psfebi@gmail.com, Indonesia ${ }^{4}$

\begin{abstract}
This research aims to analyses the economic impact of the covid 19 outbreak toward stock market in Indonesia. This research is a quantitative descriptive study by collecting various sources from journals and current case studies about covid 19 outbreak. The technique of collecting data uses quotations and related news. The results in this study isThe covid-19 pandemic outbreak has a pretty bad impact on the capital market, where the occurrence of this pandemic has affected many investors in making investment actions which is very influential on the Stock Market.
\end{abstract}

Keywords: Economic impact; COVID 19; stock market

\section{Introduction}

In December 2020, the world was shocked by the existence of an outbreak that emerged in Wuhan, China, the Corona Virus and has now become a worldwide pandemic. COVID-19 is an infectious disease caused by the corona virus. Most people who release COVID-19 will fix an emergency problem. Covid-19 is an infectious disease that can be transmitted only by physical contact, a drop of a drophlet and through objects held by an infected person, so that transmission is very quick and easy. This virus has an incubation period of 2-14 days and then shows characteristics - such as coughing, high fever, difficulty breathing. There are also some patients who do not have publications called carriers and can infect others. Until now the virus has spread in 203 countries and shows an increase in cases per acquisition. Many countries are asking people to keep their distance (Social Compilation) of compilations traveling outside the home like China did as the country of origin of the virus, even providing Lockdown policies.

Corona Virus Disease-19 (Covid-19) according to as of March 30, 2020 has infected 199 countries with active cases 724,565 and 152,076 cured. In Indonesia, the covid 19 case was officially announced by the government on March 2, 2020 with positive 2 people. As of March 30,2020 there were 1414 positive, 122 died and 75 recovered with the distribution of 31 infected provinces. This case is getting worse and worse so that the regional and national governments give orders to school students and employees to take time off during the Covid-19 national emergency. All countries in the world also participate in restricting access to and from ports,

\footnotetext{
1hernindapitaloka2@gmail.com

2ahmadulil.asfebi@gmail.com

${ }^{3}$ ekaresmihartati3020@gmail.com

4dessyfitria.psfebi@gmail.com
} 
airports and land routes. It has been established by WHO that Covid-19 is a global pandemic so that many human activities are disrupted, including the country's vital activities in the economic sector. Co-19 and the global economy of the US, China, Japan, Germany, Britain, France and Italy are the countries most affected by this outbreak. the 7 countries (G7) control $60 \%$ of world demand and supply (GDP), $65 \%$ of world manufacturing, $41 \%$ of world manufacturing exports. This figure can already explain to us that this epidemic is very influential for the economies of the major countries in the world because of its highly infectious nature. When this plague plagues the country's economy. Covid-19 also caused the flow of capital in several countries to decrease. This is not without reason, because the panic that hit lowered the level of market confidence, especially in countries that are slow in stopping the spread of the virus(Baldwin \& Mauro, 2020).

For regional stock markets, in early March 2020, in the Asian region generally weakened sharply by investors who feared the rapid spread of the corona virus outbreak in wild market movements. The Nikkei index has been monitored for the week ending sharply lower to 17,431. The current market range is between resistance levels at 19973 and 21720 levels, while support at 16690 and 16111. Meanwhile, the Hang Seng Index in Hong Kong last week ended lower to 24.033. This week will be between resistance levels at 25561 and 27067, while support at 22519 and 21492. The Wall Street stock market has been observed to have eroded through volatile markets, having fallen the most since the 1987 crash and on the last day the $9 \%$ rebound was the strongest since 2008 by stimulus plans and handling corona viruses from the Trump administration(McKibbin \& Fernando, 2020). The Dow Jones index weakened weekly to $23,185.62$, with the next market range between resistance levels at 25021 and 27102, while support at 21154 and 20553. The S\&P 500 index last week weakened to 2,711.02, with the next market range between resistance at 2883 and 3133, while support at 2478 and 2346 levels.

Indonesia's capital market sector was also shaken by this virus. The weakening of the JCI negative market sentiment and the effect of the weakening of the world stock exchanges drove the Indonesian CSPI on the red line.

In addition, the weakening of the rupiah is also a factor weakening CSPI in Indonesia Investors' concerns increased when the government announced a National Emergency and holiday policy on March 7, 2020. On trading Tuesday, March 24, 2020, the composite stock price index closed down $1.3 \%$ at the level 3,937. JCI has also touched its lowest position for the past eight years. JCI had fallen at the level of 3,000, namely on June 24, 2012 at 3,955.58. Based on the description above, researchers are interested in conducting research the impact of Covid-19 on the capital market in Indonesia for the period 2 March 2020-30 March 2020 based on data and infographics that have been available on the official JCI website and a government press conference.

\section{Research Method}

This research is a quantitative descriptive study by collecting various sources from journals and current case studies about covid 19 outbreak. The technique of collecting data uses quotations and related news. This study analyzes covid 19 outbreak toward economies in Indonesia especially the stock market.

\section{Result and Discussion}

Early on the emergence of this virus in Wuhan, China, investors were indeed quite reactive. Some of them shifted their portfolios to US dollars (gold) and gold to look for a safe attitude (flight to quality). First, the JCI began to decline even though Indonesia had not yet stated its first case, then there were large outflows because foreign investors took a bigger net sell than net buy as a reaction to the spread of this virus in various countries. However, in early February 2020 , some observers of the capital market predict that this will only be temporary or temporary, it will only last for the next two to three months, then the market will return to normal. Second, there was a panic selling which was quite high in intensity in the Indonesian capital market. They are quite afraid of the bad possibilities that occur in the future, especially Covid-19 vaccine is not 
yet known as an antidote and it is not certain when it will stop. The movement of issuer's stock prices can indicate the conditions for investors to make decisions in investment, whether the decision to buy, sell, or hold(Astikawati \& Relita, 2017), but at the beginning of the emergence of this virus has shown a significant decline in emitem stock prices so that investors choose selling to save their assets.

In this case there are 2 types of investors, namely conservative investors, those who avoid assets that have sentiment towards this pandemic, namely stocks and bonds, and the second is aggressive investors, those who are closer to assets with high risk, where assets these assets will decrease in one or 2 months but are expected to return to normal in the future(Miswanto, 2012). In the midst of this pandemic, conservative investors will tend to choose "hold cash" rather than investing its assets in the capital market. This is because investors prioritize the purchase of basic needs in the midst of physical distancing rather than prioritizing investments and their investment orientation is only short-term, so that in uncertain circumstances they prefer to secure their assets to other safe savings such as gold. Different again with aggressive investors, they tend not to sell their shares or panic selling because in the midst of the current stock decline, they take advantage of the situation to buy shares that are expected to rise again after the pandemic is over. So they do "buy installments" for a long-term investment orientation.

Indonesia had experienced a fairly severe economic crisis in 2008 that caused financial institutions and corporations. The 2008 crisis originated from America which has an impact on countries in the world. There was a significant decrease at that time. The decline in DJI (Dow Jones Industrial), which is an American stock market index, has caused American and European investors to experience a liquidity crisis that has also affected JCI(Abd. Majid, 2017). On the other hand, domestic investors were also hit by panic and uncertainty about the state of the economy, which also caused the JCI to plummet. The positive effect of shock will occur within a period of 12 months(Nezky, 2013). After this period, the JCI will respond negatively (negatively) from DJI. This was caused by the re-entry of funds marked by the growth of domestic investor confidence that attracted foreign investors to invest their funds in the CSPI. According to the IRF (Impulse Response Function) the DJI shock will be neutral (no more influence) within a period of 40 months. In this period, it is estimated that investors, both domestic and foreign, have received certainty about the economic conditions so that there is no longer the effect of DJI's shock. In 2009, the economy and the capital market sector began to improve, in Indonesia alone CSPI began to strengthen and the rupiah strengthened. It can be said, the 2008 crisis is a crisis that can be predicted to improve again.

In contrast to the Covid-19 crisis, there are no definitive estimates. This pandemic continues to spread and spread very quickly from day to day. The Jakarta Composite Index (JCI) continued to decline, followed by a sharp weakening of the rupiah. Because this pandemic is talking about humans, even survival has made this crisis even more difficult to deal with. The IMF has confirmed that the current crisis is even worse than 2008. In this case, the IMF received many requests for loans, even the largest, with more than 90 countries asking for loans to meet the needs of affected countries. The most severe is developing countries, because the economy is not yet stable coupled with a crisis that causes investors to withdraw funds again, especially now it is not talking about anxiety, but has reached a level of fear. This is far worse than the global financial crisis, and some countries rely heavily on commodity exports. When prices fall, a country like Indonesia, which relies heavily on exports and capital from investors, will be hit, making the economy more devastated and collapse. Although after the peak of the problem there will be a time when the problem subsides (Fernando, 2020), but it is quite biased in logic that this pandemic which has lasted 3 months is enough to destroy the world economy quite significantly, so it will take a long time to recover situation because all countries around the world also think of their own country's interests to restore the situation.

In handling covid-19 outbreaks, the Indonesian government has prepared several stimulus scenarios, including capital market stimulus in Indonesia. The Indonesian government has provided several capital market stimulus, namely; First, Buyback of shares by the company 
without having to wait for approval from the General Meeting of Shareholders (GMS), and the maximum number of shares resulting from repurchase (treasury stock) increased from $10 \%$ to $20 \%$ of the paid up capital. Second, Extension of the deadline for submitting the 2020 Interim Financial Statements for companies listed for two months from the financial reporting deadline, as referred to in the IDX regulations. With the extension of the deadline, the IDX will adjust the imposition of special "L" notation in the Listed Company code. Third, Prohibition of short selling transactions for all Exchange members starting on 2 March until the deadline that has not been determined by the OJK. And Fourth The government also provides stimulus in the banking sector to save the increase in bad loans in Indonesia (Disemadi, 2019).

Apart from some of the above stimulus according to PERPPU No.1 / 2020, it contains a mandate aimed at the government and Bank Indonesia (BI) to do things out of the ordinary, even outside the legislation, such as the government is allowed to widen the budget deficit above $3 \%$ of Gross Domestic Product (GDP), BI is allowed to enter Government Securities (SBN) auctions on the primary market. From some of the above policies, especially in raising the budget deficit on GDP, this will provide excessive confidence for investors. From some of the capital market stimulus by the government there was an increase in the IHSG where this happened in April, as we know that on March 22-24 became the lowest point of the IHSG.

The problems faced related to Covid-19 required the existence of prevention or the right solution. Among other things, when the epidemic lasts a long time, the government, aside from providing stimulus or injecting funds into the capital market, can move domestic investors to be more active in investing in our capital markets so that we will gradually become stronger or stable. For investors, we can deal with a buy and hold system. The ultimate goal with investing is to build wealth in the future, and this takes time. Investing as a long-term game and by means of investors will not be stressed about the possibility of daily volatility.

\section{Conclusions}

The covid-19 pandemic outbreak has a pretty bad impact on the capital market, where the occurrence of this pandemic has affected many investors in making investment actions which is very influential on the IHSG. In case, American crisis in 2008 and the Covid-19 case there were differences where in the 2008 case it was still predictable with certainty regarding recovery from the crisis so that investors could still predict when the capital market conditions would improve, in contrast to the Covid-19 case where it was very difficult to predict why the end of this crisis and the improvement in capital market conditions. In facing the co-19 crisis, the government also provided a number of stimuli, where these stimuli had a good impact on the Jakarta Composite Index, if this co-19 lasted even longer, we would not know whether the IHSG conditions would remain stable, increase, and the worst possible dropped IHSG. Therefore, the government needs to mobilize investors to invest their assets in the capital market, so that the stock market will slowly stabilize. For investor, we can use "buy and hold" system for secure our investment.

\section{References}

Abd. Majid, M. S. (2017). Krisis Ekonomi Dan Solusinya Dalam Perspektif Islam: Analisis Krisis Ekonomi Global 2008. Jurnal Perspektif Ekonomi Darussalam, 1(2), 85-97. https://doi.org/10.24815/jped.v1i2.6547

Astikawati, Y., \& Relita, D. T. (2017). Pengaruh harga saham perusahaan terhadap transaksi jual beli saham di pasar modal indonesia. Jurnal Profit, 4, 134-144.

Baldwin, R., \& Mauro, B. W. di. (2020). Economics in the Time of COVID-19. In Economics in the Time of COVID-19.

Disemadi, H. S. (2019). Risk Management in the Provision of People'S Business Credit As Implementation of Prudential Principles. Diponegoro Law Review, 4(2), 194. 
https://doi.org/10.14710/dilrev.4.2.2019.194-208

McKibbin, W. J., \& Fernando, R. (2020). The Global Macroeconomic Impacts of COVID-19: Seven Scenarios. SSRN Electronic Journal. https://doi.org/10.2139/ssrn.3547729

Miswanto. (2012). Kebijakan Dalam Penentuan Dan Pendanaan Modal Kerja Perusahaan. Jurnal Economia, 8(2), 181-195. https://doi.org/10.21831/economia.v8i2.1227

Nezky, M. (2013). Pengaruh Krisis Ekonomi Amerika Serikat Terhadap Bursa Saham Dan Perdagangan Indonesia. Buletin Ekonomi Moneter Dan Perbankan, 15(3), 89-103. https://doi.org/10.21098/bemp.v15i3.69 
